\title{
KEBIJAKAN HUKUM PIDANA SEBAGAI UPAYA PENANGGULANGAN TINDAK PIDANA SATWA YANG DILINDUNGI DI INDONESIA
}

\author{
Benny Karya Limantara', Eko Soponyono²
}

\begin{abstract}
ABSTRAK
Penelitian ini mengkaji kebijakan hukum pidana dalam menentukan arah kebijakan penanggulangan tindak pidana satwa yang dilindungi di Indonesia saat ini dan pada masa yang akan datang. Kajian didasarkan pada hasil penelitian yuridis normatif untuk menemukan kaidah-kaidah dan norma-norma hukum dalam merumuskan perlindungan terhadap satwa yang dilindungi. Hasil penelitian menyimpulkan perlindungan terhadap satwa yang dilindungi saat ini masih dirasakan kurang efektif, seperti tidak adanya pengaturan pertanggungjawaban bagi korporasi dan tidak adanya pengaturan mengenai perbedaan sanksi antara satwa liar yang dilindungi dari alam dan hasil penangkaran, oleh karenanya, perlu adanya reformulasi Undang-Undang tentang Konservasi Sumber Daya Alam Hayati dan Ekosistemnya serta dimasukkannya pengaturan mengenai satwa yang dilindungi dalam RUU KUHP sebagai pijakan yuridis yang baru untuk memberikan perlindungan baik secara konkret maupun secara abstrak.
\end{abstract}

Kata Kunci : KebijakanPidana, Perlindungan, Satwa.

\begin{abstract}
This research discusses about criminal law policy in determining direction of the criminal offenseprevention policyprotected animals now in Indonesia and in the foreseeable future. The study was based on the results of research in normative jurisdiction to find a norms and principle in formulating the protection of animals. The research concludes the protection of animals are still in effective, such asthe lack ofaccountabilityforcorporateregulationand the absence ofa regulation onsanctionsdifferencebetweenanimalsfrom the natureandcaptive breeding. therefore, there needs to reformulation of the Law of Conservation of Natural Resources and Ecosystem, and the inclusion of regulation of protected animals in the Draft Criminal Code as a new juridical basis to provide the protection both in concretely and abstractly.
\end{abstract}

Keyword : Criminal Law Policy, The Protection of Reserved Animals.

\footnotetext{
${ }^{1}$ Mahasiswa Program Studi Magister IImu Hukum UNDIP

${ }^{2}$ Dosen Program Studi Magister Ilmu Hukum UNDIP
} 


\section{A. Latar Belakang}

Upaya pemenuhan kebutuhan hidup manusia, dalam penerapannya tidak segan melakukan perbuatan yang melanggar hukum dengan cara pencurian satwa yang dilindungi, seperti membunuh gajah untuk di ambil gadingnya karena mempunyai nilai ekonomis yang tinggi, dimana gadingnya dapat di buat pipa rokok dan kerajinan lainnya yang mempunyai nilai jual/konsumtif tinggi. Pasal 33 ayat (3) Undang-Undang Dasar 1945 menyatakan bahwa: “Bumi, air dan kekayaan alam yang terkandung di dalamnya dikuasai oleh negara dan dipergunakan sebesar-besarnya kemakmuran rakyat".

Hal ini berarti, konstitusi menegaskan kewajiban negara dan pemerintah untuk melindungi, melakukan pengelolaan lingkungan hidup guna kepentingan rakyat yang hidup di masa kini dan maupun yang hidup di masa yang akan datang. Penggunaan bumi, air, dan kekayaan alam yang terkandung di dalamnya untuk sebesar-besarnya kemakmuran rakyat diselenggarakan melalui upaya pembangunan.

Upaya pembangunan ini tidak berhenti dalam waktu satu atau dua tahun, melainkan merupakan suatu proses yang berkelanjutan, maka untuk menunjang proses pembangunan yang berkelanjutan itu diperlukan pula tersedianya bumi dan air dan kekayaan alam secara berkelanjutan. Sumber daya alam hayati Indonesia dan ekosistemnya memegang peranan penting bagi kehidupan masa kini dan masa depan.

Pembangunan sumber daya alam hayati dan ekosistemnya adalah bagian integral dari pembangunan nasional yang berkelanjutan sebagai pengamalan pancasila. Unsur-unsur sumber daya alam hayati dan ekosistemnya pada dasarnya saling tergantung antara satu dengan yang lainnya dan saling mempengaruhi sehingga kerusakan dan kepunahan salah satu unsurnya akan berakibat terganggunya ekosistem.

Tindakan manusia terhadap satwa yang dilindungi oleh hukum seperti gajah sumatera, trenggiling, penyu, dan binatang lainnya tersebar diseluruh pulaupulau di Indonesia, termasuk baik dalam kawasan hutan maupun di luar kawasan hutan di seluruh wilayah negara Republik Indonesia merupakan satwa yang harus dilindungi. Berlakunya Undang-Undang Republik Indonesia Nomor 5 Tahun 1990 tentang Konservasi Sumber Daya Alam Hayati dan Ekosistem nya yang merupakan produk hukum nasional agar dapat mengatur secara menyeluruh yang berkaitan dengan pemanfaatan, hubungan hukum antara manusia dengan sumber daya alam hayati dan ekosistemnya.

Bertitik tolak dari deskripsi di atas, dikaitkan dengan berbagai fenomena yang terjadi dalam dunia konservasi sumber daya alam hayati dan ekosistemnya saat ini merupakan suatu keprihatinan yang mendalam. Maraknya pelanggaran terhadap tindak pidana satwa yang dilindungi menimbulkan keprihatinan pada keseimbangan ekosistem. Pelanggaran yang terjadi terhadap satwa yang dilindungi sangat heterogen sifatnya dan dilakukan secara langsung maupun tidak langsung, secara fulgar maupun terselebung.

\footnotetext{
${ }^{3}$ Undang-undang Dasar Negara Republik Indonesia Tahun 1945 ( Jakarta:Sekretariat Jenderal dan Kepaniteraan Mahkamah Konstitusi Republik Indonesia:2011) halaman 57.
} 
Barangkali masih teringat beberapa kasus terjadi terhadap satwa yang dilindungi beberapa tahun yang lalu, misalnya : Pembantaian satwa orang utan Kalimantan (Pongo Pygmeus Morio) terjadi sejak tahun 2008-2010 lalu, terungkap ke publik pada akhir September 2011 lalu.

Mantan General Manager PT Khaleda Agroprima Malindo (KAM) Aru Mugem Samugem dinilai paling bertanggung jawab dalam pembantaian orang utan di areal PT KAM, di Desa Puan Cepak, Kutai Kartanegara. ${ }^{4}$ Kasus perdagangan satwa yang dilindungi di Pasar Burung Muntilan, Magelang, Jawa Tengah yang memperdagangkan anak buaya,anak kijang, anak kucing hutan, kukang, burung elang, bajing asal papua, dan landak. ${ }^{5}$

Kasus memelihara satwa langka yang dilindungi di Vila Pasti, Desa, Peranca, Jembrana, Provinsi Bali yaitu 2 (dua) ekor buaya muara,1 (satu) ekor burung kakak tua jambul kuning, 1 (satu) ekor burung kakak tua jambul orange, dan 1 (satu) ekor burung merak, 1 (satu) dari 2 (dua) ekor buaya muara ditemukan dalam kondisi mati dan sudah diawetkan, ${ }^{6}$ kasus penyelundupan satwa langka jenis trenggiling sejumlah 2691 (dua ribu enam ratus sembilan puluh satu) ekor dan bagiannya berupa 50 (lima puluh) kilogram sisik trenggiling ke luar negri di Sumatera selatan tahun $2008 .^{7}$

\section{Metode Penelitian}

Penelitian hukum ini merupakan penelitian hukum normatif, yang mencakup: Penelitian terhadap asas-asas hukum; Penelitian terhadap sistematika hukum; Penelitian terhadap taraf sinkronisasi vertikal dan horizontal; Perbandingan hukum; sejarah hukum. Sehingga penelitian yang digunakan oleh penulis adalah pendekatan yuridis normatif. ${ }^{8}$ Penelitian hukum yang bersifat normatif selalu menitik beratkan pada sumber data sekunder. dibedakan menjadi bahan hukum primer, bahan hukum sekunder dan bahan hukum tersier. Keseluruhan data dianalisis dengan menggunakan analisis kualititatif.

\section{Kerangka Teori}

Menurut Bambang Poernomo, hukum pidana meliputi hukum yang memberikan kekuasaan untuk ancaman pidana, menetapkan putusan dan melaksanakan pidana hanya dibebankan kepada negara atau pejabat yang ditunjuk untuk itu. ${ }^{9}$ Tindak pidana adalah perbuatan yang dilarang oleh suatu aturan hukum larangan mana disertai ancaman (sanksi) yang berupa pidana tertentu, bagi barangsiapa melarang larangan tersebut. ${ }^{10}$

Menurut Simon unsur-unsur tindak pidana atau Strafbaar Feit adalah :11 Perbuatan Manusia (Positif atau negatif), berbuat atau tidak berbuat atau

\footnotetext{
${ }^{4}$ http://news.detik.com/read/2011/11/25/184005/1775957/10/2/pt-kam-mantan-gmperintahkan-pembantaian-orang-utan (di akses tanggal 28 oktober 2013 jam 21.13 wib)

${ }^{5}$ http://regional.kompas.com/read/2013/09/18/1710271/Polisi.Ungkap.PerdaganganSatwa Langka.di.Magelang (di akses tanggal 28 oktober 2013 jam 21.34 wib)

${ }^{6}$ http://regional.kompas.com/read/2013/03/25/17085510/Polda.Bali.Amankan.5.Satwa.Langka.d i.Sebuah.Vila (di akses tanggal 28 oktober 2013 jam 21.42 wib)

${ }^{7}$ http://regional.kompas.com/read/2011/11/25/16304433/Kasus.Penyelundupan.Trenggiling.Ter banyak.di.Sumsel. (di akses tanggal 28 oktober 2013 jam 21.44 wib)

8 Peter Mahmud Marzuki, 2007, Penelitian Hukum Cetakan Kedua. Jakarta, Kencana Prenada Media Group, hlm. 35

${ }^{9}$ Bambang Poernomo,Asas-Asas Hukum Pidana, (Jakarta:Ghalia Indonesia,1997), halaman 19-20.

${ }^{10}$ Moeljatno, Azas-Azas Hukum Pidana-Edisi revisi, (Jakarta:Rineka Cipta,2008) halaman 40.

${ }^{11}$ Simon dalam Soedarto,Hukum Pidana I, (Semarang:Universitas Diponogoro,1990), halaman 40.
} 
membiarkan; Diancam dengan pidana (Straafbaar gesteid); Melawan hukum (Onrechmatig); Dilakukan dengan kesalahan (Met shuld inverband stand); Oleh orang yang mampu bertanggungjawab, (Toerekening vatbaar persoon).

Pertanggungjawaban pidana merupakan salah satu upaya penanggulangan tindak pidana yang dikemukakan oleh G.P Hoefnagels, upaya penanggulangan tindak pidana dilakukan dengan cara : Penerapan hukum pidana (Criminal Law Application); Pencegahan tanpa pidana (Prevention Without Punishment); Mempengaruhi pandangan masyarakat mengenai kejahatan dan pemidanaan lewat media masa (Influencing Views Of Society On Crime and Punishment / Mass Media). ${ }^{12}$

Pada butir (1) di atas menitik beratkan pada upaya yang bersifat represif (penindakan/pemberantasan) yaitu upaya yang dilakukan sesudah kejahatan terjadi upaya ini termasuk dalam sarana penal, sedangkan pada butir (2 dan 3) menitik beratkan pada upaya yang bersifat preventif (pencegahan/penangkalan) yaitu upaya yang dilakukan sebelum kejahatan terjadi upaya ini dikelompokkan dalam sarana non penal.

Memorie Van Toelicting menyebutkan bahwa pidana pada umumnya hendaknya dijatuhkan hanya pada barang siapa melakukan perbuatan yang dilarang, dengan dikehendaki dan diketahui. Berdasarkan Memorie Van Toelicting tersebut, kesengajaan dalam perbuatan pidana mengandung arti dikehndaki dan diketahui. Dalam teori Memorie Van Toelicting ada (2) aliran, yaitu $;{ }^{13}$ Teori Kehendak (Wilstheorie), Teori Pengetahuan (Voorstellingstheorie)

Pertanggungjawaban pidana berkaitan dengan kesalahan, dalam hukum pidana ada 2 (dua) macam yaitu sengaja (dolus/opzet) dan kealpaan (culpa) : Kesengajaan (dolus/opzet), Kurang hati-hati (kealpaan / culpa)

Perspektif yuridis di dalamnya mengandung, isu lingkungan khususnya konservasi satwa dilindungi (endangered species) yang merupakan bidang keanekaragaman hayati (biological diversity), belum mendapat perhatian besar dan prioritas dari para akademisi dan praktisi hukum, atau setidak-tidaknya sejajar dengan isu-isu dalam hukum konvensional. Salah satu penyebabnya adalah perbedaan mengenai benda yang menjadi objek perlindungan hukum. ${ }^{14}$

Ilmu hukum konvensional memfokuskan nyawa manusia, barang dengan hak kepemilikan, serta martabat/kehormatan sebagai benda hukum dan telah berlangsung lama, sedangkan yang menjadi benda hukum dalam hukum konservasi sumber daya hayati adalah makhluk hidup yang mempunyai naluri dan siklus kehidupan sendiri. Disamping itu, banyak akademisi dan praktisi hukum masih menganggap kejahatan terhadap spesies tidak langsung mengancam dan merugikan manusia sebagai subjek hukum, sehingga kejahatan ini tidak atau kurang mendapat perhatian.

Sebaliknya, perlindungan hukum terhadap lingkungan menjadi sangat penting mengingat manusia merupakan salah satu unsur dalam mata rantai kehidupan di bumi (web of life) yang menyebabkan ketergantungan (interdependecy) terhadap lingkungan biotic maupun abiotic, di dalamnya

\footnotetext{
${ }^{12}$ Barda Nawawi Arief, Bunga Rampai Kebijakan Hukum Pidana, (Jakarta:Citra Aditya Bandung,1997), Halaman 5.

${ }^{13}$ Moeljatno, halaman 185-187. Op.cit.

${ }^{14}$ http://www.dephut.go.id, Kejahatan Konservasi atas Pembunuhan Satwa Langka dilindungi.html (di akses tanggal 21 November Jam 23.45)
} 
termasuk peran besar spesies satwa yang membentuk jaringan ekosistem dan rantai makanan (food web). ${ }^{15}$

Hukum lingkungan berkembang berdasarkan pemikiran yang mengacu pada prinsip-prinsip ekologis. Untuk itu, perlu perubahan mendasar dari cara pandang terhadap prinsip-prinsip hukum yang semula bersifat eco-centris, dari hanya atas etika homo-sapiens menjadi eco-ethics. Konsekuensinya adalah adanya keharusan bagi ahli hukum untuk dapat memahami tidak saja konsep hukum, tetapi juga konsep disiplin ilmu lain yang berpengaruh, seperti biologi, ekologi, ekonomi, dan teknologi.

Kejahatan terhadap lingkungan (crimes against environment/ecocrime) seharusnya menjadi isu yang mengancam manusia sehingga mendapat perhatian bersama khususnya ahli hukum. ${ }^{16}$ Merujuk pada Undang-Undang Nomor 5 tahun 1990, tindak pidana konservasi satwa merupakan tindak pidana pengawetan keanekaragaman satwa, suatu kebijakan untuk menjaga agar keanekaragaman jenis satwa tidak punah, demikian Penjelasan Pasal 11 Undang-Undang Nomor 5 tahun 1990.

Sanksi pidana pada Pasal 40 Undang-Undang Nomor 5 tahun 1990 tidak hanya diterapkan terhadap pelaku tindak pidana pengawetan keanekaragaman spesies tumbuhan dan satwa, tapi juga atas peruntukkan serta penggunaan kawasan suaka alam dan pelestarian alam,baik sebagai kejahatan maupun pelanggaran (Pasal 40 ayat (5) Undang-Undang Nomor 5 Tahun 1990. Substansi Undang-Undang Nomor 5 Tahun 1990, terlihat bahwa wujud konkrit perlindungan hukum secara khusus diberikan melalui pengawetan keanekaragaman satwa dengan menetapkan status satwa dilindungi, yaitu satwa dalam bahaya kepunahan (thtreatened with extinction) dan satwa yang populasinya jarang atau endemik (Pasal 20 Undang-Undang Nomor 5 Tahun 1990).

Merujuk pada Pasal III ayat (3) (c) dan (5) (c) Piagam CITES tanggal 3 maret 1973 (diperbaharui tanggal 22 with juni 1979), satwa dalam bahaya kepunahan (threatened extinction) termasuk dalam kelompok Appendix I, specimen is not to be used for primarily commercial purposes). Spesies harimau sumatera (panthera tigris sumatrae) merupakan satwa dilindungi di Indonesia sejak tahun 1972 dengan Surat Keputusan Menteri Pertanian Nomor 372/Kpts/Um/7/1972, dan kembali di tuangkan pada Lampiran Peraturan Pemerintah Nomor 7 Tahun 1999 tentang Pengawetan Jenis Tumbuhan dan Satwa.

Pembunuhan satwa dilindungi secara tegas merupakan tindak pidana, sebagaimana tertuang pada Pasal 21 ayat (2) Undang-Undang Nomor 5 Tahun 1990. Adanya alasan penghapus pidana (strafuitsluitingsgrond/grounds of impunity) memang ditegaskan pada Pasal 22 Undang-Undang Nomor 5 Tahun 1990, yang dalam teori pemidanaan merupakan alasan pembenar (rechtvaardigingsground, ex Pasal 49 ayat (1) KUHP) yang dapat menghapuskan sifat melawan hukum (wederrechttelijk) perbuatan.

Salah satu perbuatan dimaksud diatur pada Pasal 22 ayat (3) UndangUndang Nomor 5 Tahun 1990, yaitu pembunuhan karena membahayakan 
kehidupan manusia (noodweer). Terkait dengan peristiwa pemburuan harimau sumatera, unsur-unsur delik yang ada pada Pasal 40 ayat (2) Undang-Undang Nomor 5 Tahun 1990 dapat diterapkan kepada para tersangka.

Berita adanya jerat yang di buat para tersangka tersebut tidak saja mengandung indikasi unsur kesengajaan (dolus/intent/opzet) dalam perbuatan yang maksudnya agar harimau mati, tetapi lebih dari itu, yaitu indikasi suatu perbuatan yang direncanakan (premeditated crime/dolus premeditatus). Oleh karena itu dalam penelitian ini penulis merumuskan rumusan masalah: Bagaimana pengaturan mengenai tindak pidana satwa yang dilindungi saat ini di Indonesia? Bagaimana sebaiknya kebijakan hukum pidana dalam menanggulangi tindak pidana satwa yang dilindungi di masa mendatang?

\section{B. HASIL PENELITIAN DAN PEMBAHASAN}

\section{Kebijakan Sistem Pengaturan Tindak Pidana Satwa Yang Di Lindungi Dalam Hukum Pidana Positif}

Pembahasan mengenai kedudukan dan pengaturan tindak pidana satwa yang dilindungi akan dijelaskan sesuai dengan dengan tiga masalah pokok/substansi pokok dari hukum pidana yaitu perbutan (masalah tindak pidana), orang (masalah kesalahan atau pertanggungjawaban pidana), dan pidana/pemidanaan. Pengaturan mengenai Tindak Pidana Satwa yang dilindungi dalam KUHP tidak ada, tapi yang paling mendekati adalah yang diatur dalam Pasal 302 dalam Bab XIV tentang kejahatan terhadap kesusilaan.

a) Tindak Pidana

Unsur dari tindak pidana yang dimaksudkan di dalam ketentuan pidana yang diatur dalam Pasal 302 ayat (1) itu ialah unsur 'dengan sengaja'. Sesuai dengan letaknya di dalam rumusan ketentuan pidana yang diatur, unsur 'dengan sengaja' tersebut meliputi unsur-unsur: a. menimbulkan rasa sakit; b. menimbulkan luka; c. merugikan kesehatan dan; d. seekor binatang.

b) Pertanggungjawaban Pidana

Perumusan Pasal 302 di atas, tentang penganiayaan hewan, pertanggungjawaban pidananya dikenakan pada orang, hal ini dapat dibuktikan Unsur Barangsiapa yang dimaksud Pasal 302 KUHP yang dapat dipertanggungjawabkan secara pidana adalah orang, hal ini dapat dipertegas dalam rumusan Pasal 59 KUHP bahwa dalam hal-hal di mana karena pelanggaran ditentukan pidana terhadap pengurus, anggota-anggota badan pengurus atau komisaris-komisaris, maka pengurus, anggota badan pengurus atau komisaris yang ternyata tidak ikut campur melakukan pelanggaran tidak dipidana.

c) Pidana dan Pemidanaan

Pembagian pidana dan pemidanaan, di dalamnya terdiri dari beberapa bagian yang akan dijelaskan dalam pembagian ini, di mulai dari pidana terlebih dahulu yang akan dijelaskan. Pidana di dalamnya terdiri dari jenis pidana (strafsoort), cara pelaksanaan pidana (strafmodus), lamanya pidana (strafmaat), dan sistem perumusan ancaman pidana.

Berdasarkan perumusan Pasal 302 di atas, terdapat 3 sub yang dapat dianalisis, yaitu ;

a). Straafmacht (lamanya sanksi pidana) 
Berdasarkan Pasal 302 KUHP lamanya sanksi pidana adalah paling lama 3 bulan penjara atau pidana denda paling banyak empat ribu lima ratus rupiah. Pidana penjara paling lama 3 bulan merupakan sistem maksimum khusus karena pengaturannya di dalam buku ke dua KUHP sedangkan sistem maksimum umum dan minimum umum diatur dalam buku ke satu KUHP.

b). Straafsoort (jenis pidana)

Berdasarkan Pasal 302 KUHP, jenis pidana yang terdapat dalam Pasal ini adalah pidana penjara dan pidana denda.

c). Sistem perumusan ancaman pidana

Berdasarkan Pasal 302 KUHP, sistem perumusan ancaman pidana yang terdapat dalam Pasal ini menganut sistem perumusan alternatif karena menggunakan kata "atau"

Undang-Undang Nomor 5 tahun 1990 tentang Konservasi Sumberdaya Alam Hayati dan Ekosistemnya (KSDAHE) yaitu pasal 40 ayat 1, 2, 3, 4, dan 5, dalam ketentuan pidana yang terdapat dalam UU Nomor 5 tahun 1990 ayat 5 membagi tindak pidana ke dalam 2 golongan yaitu tindak pidana dikatakan sebagai kejahatan untuk ayat 1 dan 2 dan tindak pidana dikatakan sebagai pelanggaran untuk ayat 3 dan 4 .

Adapun perumusan sanksi pidana dalam Undang-Undang Nomor 5 tahun

1990 tentang Konservasi Sumber Daya Alam Hayati dan Ekosistemnya tersebar dalam pasal 40 diantaranya :

(1) Barang siapa dengan sengaja melakukan pelanggaran terhadap ketentuan sebagaimana dimaksud dalam Pasal 19 ayat (1) dan Pasal 33 ayat (1) dipidana dengan pidana penjara paling lama 10 (sepuluh) tahun dan denda paling banyak Rp. 200.000.000,00 (dua ratus juta rupiah).

(2) Barang siapa dengan sengaja melakukan pelanggaran terhadap ketentuan sebagaimana dimaksud dalam Pasal 21 ayat (1) dan ayat (2) serta Pasal 33 ayat (3) dipidana dengan pidana penjara paling lama 5 (lima) tahun dan denda paling banyak Rp. 100.000.000,00 (seratus juta rupiah).

(3) Barang siapa karena kelalaiannya melakukan pelanggaran terhadap ketentuan sebagaimana dimaksud dalam Pasal 19 ayat (1) dan Pasal 33 ayat (1) dipidana dengan pidana kurungan paling lama 1 (satu) tahun dan denda paling banyak Rp. 100.000.000,00 (seratus juta rupiah).

(4) Barangsiapa karena kelalaiannya melakukan pelanggaran terhadap ketentuan sebagaimana dimaksud dalam Pasal 21 ayat (1) dan ayat (2) serta Pasal 33 ayat (3) dipidana dengan pidana kurungan paling lama 1 (satu) tahun dan denda paling banyak Rp. 50.000.000,00 (lima puluh juta rupiah).

(5) Tindak pidana sebagaimana dimaksud pada ayat (1) dan ayat (2) adalah kejahatan dan tindak pidana sebagaimana dimaksud pada ayat (3) dan ayat (4) adalah pelanggaran

Pengaturan mengenai Tindak Pidana Satwa Dilindungi di dalam Undang-Undang Nomor 5 Tahun 1990 terdapat dalam Pasal 40 ayat 2

1) Unsur Perbuatan

Dalam Pasal 40 ayat 2 di atas, barangsiapa melanggar Pasal 21 ayat 2 yang berbunyi, setiap orang dilarang untuk: 
a. menangkap, melukai, membunuh, menyimpan, memiliki memelihara, mengangkut, dan memperniagakan satwa yang dilindungi dalam keadaan hidup;

b. menyimpan, memiliki, memeilihara, mengangkut, dan memperniagakan satwa yang dilindungi dalam keadaan mati;

c. mengeluarkan satwa yang dilindungi dari suatu di Indonesia ke tempat lain di dalam atau diluar indonesia;

d. memperniagakan, menyimpan atau memilik kulit, tubuh, atau bagianbagian lain satwa yang dilindungi atau barang-barang yang dibuat dari bagian-bagian tersebut atau mengeluarkannya dari suatu tempat di Indonesia ke tempat lain di dalam atau di luar Indonesia

e. mengambil, merusak, memusnahkan, memperniagakan, menyimpan atau memiliki telur dan atau sarang satwa yang dilindungi.

\section{2) Kualifikasi Yuridis}

Kualifikasi yuridis, sebagaimana telah dijelaskan di atas adalah merupakan hal yang penting sebab jika undang-undang khusus tidak mencantumkan suatu delik apakah sebagai kejahatan atau pelanggaran maka akan menimbulkan permasalahan yuridis dalam penerapan hukumnya di lapangan, dalam hal terjadi pecobaan, pembantuan, penyertaan, perbarengan tindak pidana dan lain-lain, sebagaimana telah dicontohkan di atas.

Dalam Undang-Undang ini, kualifikasi yuridis terdapat di Pasal 40 ayat 2 yang berbunyi: Tindak pidana sebagaimana dimaksud pada ayat (1) dan ayat (2) adalah kejahatan dan tindak pidana sebagaimana dimaksud pada ayat (3) dan ayat (4) adalah pelanggaran.

1. Pertanggungjawaban Pidana

Pertanggungjawaban pidana pada Undang-Undang khusus ini terdapat dalam Pasal 40 ayat 2 yang berbunyi:

"Barangsiapa dengan sengaja melakukan pelanggaran terhadap ketentuan sebagaimana dimaksud dalam Pasal 21 ayat (1) dan ayat (2) serta Pasal 33 ayat (3) dipidana dengan pidana penjara paling lama 5 (lima) tahun dan denda paling banyak Rp.100.000.000,00 (seratus juta rupiah)".

Perumusan Pasal 40 ayat (2) di atas, tentang tindak pidana terhadap hewan, pertanggungjawaban pidananya dikenakan kepada orang, hal ini dapat dibuktikan dari Unsur Barangsiapa yang dimaksud Pasal 40 ayat (2) yang dapat dipertanggungjawabkan secara pidana adalah orang, hal ini dipertegas dalam rumusan Pasal 59 KUHP bahwa dalam hal-hal di mana karena pelanggaran ditentukan pidana terhadap pengurus, anggota-anggota badan pengurus atau komisaris-komisaris, maka pengurus, anggota badan pengurus atau komisaris yang ternyata tidak ikut campur melakukan pelanggaran tidak dipidana.

2. Masalah Pidana dan Pemidanaan

Dalam Undang-undang Nomor 5 Tahun 1990 menganut sistem pidana maksimal khusus dan jenis nya terdiri dari pidana penjara dan pidana denda (menganut sistem perumusan ancaman pidana kumulatif menggunakan kata "dan", di mana hakim dalam manjatuhkan putusannya harus menjatuhkan kedua sanksi pidana yang diatur dalam rumusan pasal yaitu pidana penjara dan denda. 


\section{Kebijakan Pengaturan Tindak Pidana Satwa yang di Lindungi Dalam Sistem Hukum Nasional Yang Akan Datang \\ a). Kedudukan dan Pengaturan Tindak Pidana Satwa yang Di Lindungi Dalam Sistem Hukum Nasional yang Akan Datang}

Tindak Pidana terhadap satwa yang dilindungi pada masa yang akan datang pada dasarnya belum diterapkan dalam Konsep RUU KUHP Tahun 2012 yang hingga kini tidak kunjung di sahkan, terdapat ketentuan Pasal yang mendekati yaitu di bagian kesembilan tentang penganiaayaan hewan Pasal 501.

Tindak pidana "penganiayaan ringan terhadap hewan" yang dimaksudkan dalam ketentuan pidana yang diatur dalam Pasal 501 RUU KUHP itu adalah:

1. Dengan sengaja menyakiti atau melukai hewan atau merugikan kesehatannya tanpa tujuan yang patut atau dengan melampaui batas yang diperlukan untuk mencapai tujuan tersebut.

2. Dengan sengaja tanpa tujuan yang patut atau dengan melampaui batas yang diperlukan untuk mencapai tujuan tersebut, tidak memberi makan atau kebutuhan hidup kepada hewan yang seluruhnya atau sebagian adalah kepunyaannya dan ada di bawah pengawasannya, atau kepada hewan yang wajib dipeliharanya.

3. Dengan sengaja melakukan persetubuhan dengan hewan.

Pertanggungjawaban pidana atau kesalahan sebagaimana telah di jelaskan di atas menurut Sudarto terdiri dari kesengajaan dan kealpaan. Kesengajaan di sini dibagi lagi berdasarkan tingkatan coraknya yaitu, kesengajaan dengan maksud, kesengajaan dengan sadar kepastian dan kesengajaan dengan sadar kemungkinan. Pertanggungjawaban pidana terhadap penganiayaan ringan hewan di RUU KUHP yang terdapat dalam Pasal 501 adalah untuk orang karena tidak ada keterangan mengenai korporasi.

Berdasarkan perumusan Pasal 501 diatas, terdapat 3 sub yang dapat di analisis berdasarkan pidana dan pemidanaan, yaitu ;

a. Straafmaht (lamanya sanksi pidana)

Berdasarkan Pasal 501 RUU KUHP lamanya sanksi pidana adalah paling lama 6 bulan penjara atau pidana denda paling banyak kategori 2. Sanksi bisa bertambah menjadi 1 tahun jika mengakibatkan sakit lebih dari 1 (satu) minggu, cacat, luka berat, atau mati.

b. Straafsoort (jenis pidana)

Berdasarkan Pasal 501 RUU KUHP, jenis pidana yang terdapat dalam Pasal ini adalah pidana pokok yaitu pidana penjara dan pidana denda.

c. Sistem perumusan ancaman pidana

Berdasarkan Pasal 501 RUU KUHP, sistem perumusan ancaman pidana yang terdapat dalam Pasal ini menganut sistem perumusan alternatif karena menggunakan kata "atau".

Peraturan Perundang-undangan yang mengatur tentang tindak pidana Satwa yang dilindungi pada Undang-undang Nomor 5 Tahun 1990 ada penyebutan atau pengklasifikasian secara yuridis antara 
kejahatan dan pelanggaran. Dalam bab Ketentuan Pidana harus ada ketentuan/penegasan tentang kualifikasi yuridis dari tindak pidana sebagai Kejahatan atau Pelanggaran, karena aturan umum KUHP terdiri dari aturan umum untuk Kejahatan dan aturan umum untuk Pelanggaran. Penempatan kualifikasi delik sebagai "kejahatan" atau "pelanggaran" pada hakikatnya merupakan penetapan kualifikasi yuridis yang mempunyai akibat yuridis pula baik yuridis materiil yang terkait pada aturan umum KUHP maupun konsekuensi yuridis formal dalam KUHAP (Kitab Undang-undang Hukum Acara Pidana), sepanjang tidak ditentukan lain oleh undang-undang. Penetapan kualifikasi yuridis yang diperlukan untuk menjembatani berlakunya aturan umum KUHP terhadap hal-hal yang tidak diatur dalam undang-undang di luar KUHP dengan mengidentikkan penetapan kualifikasi yuridis terhadap suatu perbuatan tindak pidana satwa yang dilindungi.

Masalah pidana minimal khusus memang penyimpangan dari sistem induk hukum pidana yaitu KUHP, sebagaimana telah dijelaskan di atas acaman pemidanaan minimum khusus tidak dianut oleh KUHP, hal ini dimungkinkan bagi undang-undang khusus di luar KUHP untuk membuat aturan yang menyimpang berdasarkan ketentuan dalam Pasal 103 KUHP, numun acaman minimal khusus tidak dapat begitu saja diberlakukan dengan hanya dicantumkan dalam rumusan Pasalnya saja. Perlu juga dimuat aturan atau pedoman pidana minimal khusus untuk dapat diterapkannya ancaman pidana minimal khusus terhadap tindak pidana satwa yang dilindungi.

Ancaman pidana minimal khusus juga hendaknya ditetapkan secara berpola, sebagai bahan disusunnya pola minimal khusus, dapat kiranya dikemukakan pola minimal khusus menurut Konsep RKUHP sebagai berikut: ${ }^{17}$

a. Pada prinsipnya pidana minimal khusus merupakan suatu perkecualian, yaitu untuk delik-delik tertentu yang dipandang sangat merugikan, membahayakan atau meresahkan masyarakat dan delik-delik yang dikualifisir atau diperberat oleh akibatnya (Erfolgsqualifizierte Delikte). Sebagai ukuran kuantitatif adalah delik-delik yang diancam pidana penjara di atas 7 tahun (sampai pidana mati) sajalah yang dapat dikenakan minimal khusus, karena delik-delik itulah yang digolongkan sangat serius, namun dalam hal-hal tertentu patokan itu dapat diturunkan pada delik-delik tergolong berat yaitu yang diancam 4-7 tahun penjara).

b. Adapun pola minimal khusus menurut Konsep berkisar antara 1-5 tahun dengan kategori sebagai berikut:

\begin{tabular}{l|l|l|} 
Kategori & Ancaman & Ancaman \\
\hline
\end{tabular}

17 Op. cit. Barda Nawawi Arief, Kebijakan Formulasi Ketentuan Pidana dalam Perundangundangan, Halaman 94. 


\begin{tabular}{|c|c|c|}
\hline Delik & Maksimal & Minimal \\
\hline 1. Berat & $\begin{array}{c}4 \text { sampai } 7 \\
\text { tahun }\end{array}$ & 1 tahun \\
\hline $\begin{array}{l}\text { 2. Sangat } \\
\text { serius }\end{array}$ & $\begin{array}{c}\text { 7 sampai } 10 \\
\text { tahun }\end{array}$ & 2 tahun \\
\hline & $\begin{array}{c}12 \text { sampai } \\
15 \text { tahun }\end{array}$ & 3 tahun \\
\hline & $\begin{array}{c}\text { Mati/Seumur } \\
\text { Hidup }\end{array}$ & 5 tahun \\
\hline
\end{tabular}

Penentuan minimal khusus disasarkan atau dibedakan menurut ancaman maksimal khusus untuk delik bersangkutan. Ini hanya sekedar patokan objektif atau patokan formal. Tidak setiap delik yang termasuk dalam kategori seperti di atas, harus diberi minimal khusus. Dalam menetapkan minimal khusus perlu dipertimbangkan akibat dari delik yang bersangkutan terhadap masyarakat luas (antara lain: menimbulkan bahaya keresahan umum, bahaya bagi nyawa/kesehatan/lingkungan atau menimbulkan akibat mati) atau faktor pengulangan tindak pidana (recidive). Pada umumnya delikdelik yang sangat serius sajalah yang diberi ancaman minimal khusus. Menurut Konsep ancaman minimal khusus inipun dalam halhal tertentu tetap dapat dikurangi atau dapat diperingan apabila Jenis pidana/tindakan untuk korporasi yang kebanyakan hanya berupa denda (bersifat financial sanction), jarang yang berupa "Structural sanction" atau "restriction on enterpreneurial activities" (pembatasan kegiatan usaha, pembubaran korporasi) dan "Stigmatising sanction" (pengumuman keputusan hakim, teguran korporasi). ${ }^{18}$ Kedepannya para pembentuk undang-undang hendaknya menyertakan jenis pidana atau tindakan bagi korporasi selain pidana denda.

Undang-undang yang berkaitan dengan tindak pidana satwa yang dilindungi di masa yang akan datang hendaknya memuat halhal yang belum diatur yaitu pedoman pemidanaan bagi korporasi untuk tindak pidana satwa yang dilindungi di masa yang akan datang seperti yang diatur dalam Konsep KUHP Tahun 2012 antara lain:

- Penegasan korporasi sebagai subjek tindak pidana.

- Penentuan sanksi pidana/tindakan untuk korporasi.

- Penentuan kapan korporasi dapat dipertanggungjawabkan.

- Penentuan kapan pengurus dapat dipertanggungjawabkan.

- Penentuan alasan pembenar dan pemaaf bagi korporasi.

Selain itu perlu juga menambahkan hal-hal yang berkaitan dengan pidana tambahan yang dapat dijatuhkan tersendiri tanpa dibarengi dengan pidana pokoknya dan pedoman pengganti denda untuk korporasi seperti yang diatur dalam Konsep KUHP 2012, sebagai berikut:

\footnotetext{
${ }^{18}$ Op. Cit. Cristina de Magile dalam Barda Nawawi Arief, Kebijakan Formulasi Ketentuan Pidana Dalam Peraturan Perundang-undangan, (Semarang: Pustaka Magister, 2012), Halaman 52.
} 
1. Pedoman penjatuhan pidana tambahan yang dapat dijatuhkan sendiri tanpa didahului dengan pidana pokok seperti yang terdapat dalam Pasal 67 ayat (2) Konsep yaitu:

Pidana tambahan dapat dijatuhkan bersama-sama dengan pidana pokok, sebagai pidana yang berdiri sendiri atau dapat dijatuhkan bersama-sama dengan pidana tambahan yang lain.

2. Pedoman pidana pengganti denda untuk korporasi jika denda tidak dibayar seperti dalam Pasal 85 Konsep yaitu:

Jika pengambilan kekayaan atau pendapatan sebagaimana dimaksud dalam Pasal 82 ayat (2) tidak dapat dilakukan maka untuk korporasi dikenakan pidana pengganti berupa pencabutan izin usaha atau pembubaran korporasi.

Kajian perbandingan dalam hukum pidana dengan membandingkan beberapa pengaturan di negara-negara lain dikatakan sangat penting karena menurut sudarto, ada dua manfaat mempelajari sistem hukum asing itu: ${ }^{19}$

a. Yang bersifat umum

1) Memberi kepuasan bagi orang yang ingin tahu yang bersifat ilmiah;

2) Memperdalam pengertian tentang pranata masyarakat dan kebudayaan sendiri;

3) Membawa sikap kritis terhadap sistem hukum sendiri.

b. Yang bersifat khusus

Sehubungan dengan dianutnya asas nasional aktif dalam KUHP kita. Bertolak dari uraian di atas, maka perbandingan hukum pidana tentang satwa yang dilindungi akan dibahas antara lain dari negara Inggris dan Thailand yang memuat pengaturan tentang tindak pidana satwa yang dilindungi. Van Apeldorn sendiri membedakan tujuan perbandingan hukum dalam tujuan yang bersifat teoritis dan tujuan yang bersifat praktis. Tujuan yang bersifat teoritis menjelaskan hukum sebagai gejala dunia (universal) dan oleh karena itu ilmu pengetahuan hukum harus dapat memahami gejala dunia tersebut; dan untuk itu harus dipahami hukum di masa lampau dan hukum di masa sekarang. Tujuan yang bersifat praktis dari perbandingan hukum adalah merupakan alat pertolongan untuk tertib masyarakat dan pembaharuan hukum nasional serta memberikan pengetahuan mengenai berbagai peraturan dan pikiran hukum kepada pembentuk undang-undang dan hakim. ${ }^{20}$

\section{a. Inggris}

Lamanya sanksi pidana yang terdapat dalam KUHP Inggris lebih besar dari pada sanksi yang diterapkan dalam KUHP Indonesia. Di KUHP Inggris terdapat sanksi bagi orang yang dengan sengaja menyebarkan infeksi virus terhadap hewan yang sanksi nya mencapai 7 tahun penjara, pengaturan ini tidak terdapat dalam KUHP Indonesia maupun Undang-Undang Nomor 5 Tahun 1990.

19 Barda Nawawi Arief, Perbandingan Hukum Pidana, (Jakarta: RajaGrafindo Persada, 2011), Halaman 25.

${ }^{20}$ Van Apeldorn dalam Romli Atmasasmita, Perbandingan Hukum Pidana, (Bandung: Mandar Maju, 1996), Halaman 12. 
Jenis sanksi yang terdapat dalam KUHP inggris hampir sama dengan KUHP Indonesia maupun Undang-Undang Nomor 5 Tahun 1990 yaitu penjara dan denda tetapi sistem perumusan ancaman pidana nya berbeda karena KUHP Inggris menggunakan alternatif/kumulatif yang membuat hakim bisa menjatuhkan kedua sanksi baik itu penjara maupun denda.

\section{b. Thailand}

Undang-Undang tentang penganiayaan hewan di Thailnd adalah Wild Animal Reservation and Protection act B.E. 2535 $(1992)^{21}$, Undang-undang khusus ini mengatur dengan jelas tata cara bagaimana satwa dan bagian-bagiannya jika masyarakat ingin Berburu, mengembangbiakan, Memiliki, Memperdagangan Hasil dari Satwa Liar, satwa liar yang dilindungi dan Bagian-bagiannya tersebut. Dalam Undang-undang Nomor 5 Tahun 1990 tak ada pengaturan mengenai hal di atas secara jelas karena pembahasan tentang pengawetan dan pemanfaatan satwa dan tumbuhan diatur lebih lanjut oleh Peraturan Pemerintah.

Berdasarkan Pasal yang terdapat dalam Bab 8 tentang sanksi, sistem perumusan ancaman pidana yang terdapat di dalam Pasal-Pasal ini adalah sistem perumusan ancaman alternatif/kumulatif atau gabungan karena menggunakan "atau/dan", dimana hakim dapat menjatuhkan dua jenis sekaligus ancaman pidana yang ada, atau dapat hanya memilih salah satu saja

\section{SIMPULAN DAN SARAN}

Berdasarkan pembahasan yang telah diuraikan di atas dapat diambil kesimpulan sebagai berikut:

1. Kebijakan hukum pidana saat ini, khususnya kebijakan formulasi tindak pidana satwa yang dilindungi masih terdapat beberapa ketidak sinkronisasian antara sistem induk KUHP dengan undang-undang khusus yang mengatur tentang tindak pidana satwa yang dilindungi baik pada masalah tindak pidana, masalah pertanggungjawaban pidana maupun masalah pidana dan pemidanaan yang dapat menimbulkan permasalahan yuridis.

2. Penganiayaan terhadap hewan pada masa yang akan datang telah tercantum dalam konsep RKUHP 2012, upaya perlindungan nya hanya terbatas pada hewan secara umum, bukan di khususkan kepada hewan yang seharusnya dilindungi karena bahaya kepunahan. Berdasarkan kajian berbagai negara (Inggris dan Thailand) masih terdapat beberapa kelemahan dalam UndangUndang khusus kita yaitu tak ada pengaturan mengenai tindak pidana yang dilakukan oleh korporasi dan tak adanya sanksi terhadap perbedaan antara satwa liar yang dilindungi dari alam dan satwa liar yang dilindungi hasil penangkaran

\section{Saran}

${ }^{21}$ Wildlife_Reservation_Protection_Act_2535_en.pdf (di akses kamis 30 Januari pukul 08.15) 
Berdasarkan kesimpulan di atas maka penulis merekomendasikan hal-hal sebagai berikut:

1. Sistem ancaman minimum khusus juga pengaturan mengenai pedoman pemidanaan bagi sistem ancaman minimum khusus harus termuat dalam Undang-undang yang terdapat tindak pidana satwa yang dilindungi di Indonesia.

2. Sebaiknya pertanggungjawaban pidana bagi korporasi dan pedoman pemidanaan bagi korporasi seperti halnya yang diatur dalam Konsep KUHP 2012 harus terdapat dalam Undang-undang yang mengatur tentang tindak pidana satwa yang dilindungi.

3. Sebaiknya masalah sanksi (straafmaat) perlu dinaikkan karena penjara maksimal 5 tahun dan denda maksimal Rp.100.000.000,- (Seratus juta rupiah) terlalu kecil apalagi tak ada pengaturan dan pedoman minimal khusus sehingga menimbulkan disparitas pidana

4. Pengaturan tentang pengulangan tindak pidana (recidive) perlu diatur mengingat pengulangan tindak pidana di KUHP di atur di buku II dan buku III sehingga hanya berlaku bagi tindak pidana dalam KUHP saja.

5. Perlunya memasukkan kajian mengenai tindak pidana satwa yang dilindungi di RKUHP yang akan datang dikarenakan di KUHP saat ini dan konsep 2012 hanya mencantumkan kejahatan terhadap hewan biasa.

\section{DAFTAR PUSTAKA}

Bambang Poernomo,Asas-Asas Hukum Pidana, (Jakarta:Ghalia Indonesia,1997),

Barda Nawawi Arief, Kebijakan Formulasi Ketentuan Pidana dalam Perundangundangan,

Barda Nawawi Arief, Perbandingan Hukum Pidana, (Jakarta: Raja Grafindo Persada,2011),

Barda Nawawi Arief, Perbandingan Hukum Pidana, (Jakarta: RajaGrafindo Persada, 2011),

Cristina de Magile dalam Barda Nawawi Arief, Kebijakan Formulasi Ketentuan Pidana Dalam Peraturan Perundang-undangan, (Semarang: Pustaka Magister, 2012),

Moeljatno, Azas-Azas Hukum Pidana-Edisi revisi, (Jakarta:Rineka Cipta,2008)

Peter Mahmud Marzuki, 2007, Penelitian Hukum Cetakan Kedua. Jakarta, Kencana Prenada Media Group,

Simon dalam Soedarto,Hukum Pidana I, (Semarang:Universitas Diponogoro,1990), Barda Nawawi Arief, Bunga Rampai Kebijakan Hukum Pidana, (Jakarta:Citra Aditya Bandung,1997),

Soerjono Soekanto dan Sri Mamuji, 2012, Penelitian Hukum Normatif "Suatu Tinjauan Singkat", Jakarta, PT Raja Grafindo Persada, Cet- 14

Undang-undang Dasar Negara Republik Indonesia Tahun 1945 ( Jakarta:Sekretariat Jenderal dan Kepaniteraan Mahkamah Konstitusi Republik Indonesia:2011)

Van Apeldorn dalam Romli Atmasasmita, Perbandingan Hukum Pidana, (Bandung: Mandar Maju, 1996), 
Wildlife_Reservation_Protection_Act_2535_en.pdf (di akses kamis 30 Januari pukul 08.15) 